\title{
CHARACTERIZATION OF THE SURFACES OF PHOSPHATES BY XPS .
}

\author{
AKIO TADA, MOTOI TAKAHASHI, AND NORIYASU OKAZAKI \\ Department of Applied and Environmental Chemistry, Kitami Institute of Technology, \\ Kitami, Hokkaido, 090-8507 Japan
}

\begin{abstract}
Surface characterization of $\mathrm{AlPO}_{4}$ and $\mathrm{BPO}_{4}$ was carried out by XPS. The followings were verified. The surface acid-base property of amorpous $\mathrm{AlPO}_{4}$ was similar to that of $\mathrm{Al}_{2}\left(\mathrm{SO}_{4}\right)_{3}$ but it was different from that of $\mathrm{Al}_{2} \mathrm{O}_{3}$. The amount of basic sites of amorpous $\mathrm{AlPO}_{4}$ was less than that of $\mathrm{Al}_{2} \mathrm{O}_{3}$, and the phosphorus and oxygen of amorpous $\mathrm{AlPO}_{4}$ surface partly desorbed when it was heat-treated in a vacuo. In addition, it was clarified that unreacted $\mathrm{H}_{3} \mathrm{BO}_{3}$ or its condensation compound, and $\mathrm{P}_{2} \mathrm{O}_{5}$-like phosphorus compounds remained on the surface of $\mathrm{BPO}_{4}$ as minor conponents.
\end{abstract}

\section{INTRODUCTION}

In the case of suface functional solid materials such as adsorbent, catalyst, etc., it is necessary to evaluate the composition and chemical state of the surface compounds. Though $\mathrm{X}$-ray photoelectron spectroscopy (XPS) is an effective tool for the above evaluation, there are a few studies on the surface characterization of phosphates by XPS ${ }^{1}$. Here, $\mathrm{AlPO}_{4}$ and $\mathrm{BPO}_{4}$ were employed as phosphate samples and the composition and chemical state of the surface compounds were studied, because $\mathrm{AlPO}_{4}$ is used widely as a solid acid catalyst ${ }^{2}$, a catalyst support ${ }^{3}$, etc., and $\mathrm{BPO}_{4}$ is investigated as a promissing solid acid catalyst for olefin oligomerization ${ }^{4}$, olefin skeletal isomerisation ${ }^{5}$, etc 6 .

\section{EXPERIMENTAL}

\section{Samples}

$\mathrm{AlPO}_{4}$

Cristobalite type $\mathrm{AlPO}_{4}{ }^{7}$ was prepared by dehydrating $\mathrm{AlPO}_{4} \cdot 2 \mathrm{H}_{2} \mathrm{O}(\mathrm{APO}-1)^{7}$ in an organic solvent followed by drying the precipitate and calcining the dried product. Amorphous $\mathrm{AlPO}_{4}{ }^{8}$ was prepared as follows. An aqueous solution containing an equimolar mixture of aluminum nitrate and phosphoric acid was neutralized with aqueous ammonia,

Received June 18, 2001; Accepted August 6, 2001 
and then the precipitate was dried and calcined.

$\mathrm{BPO}_{4}$

$\mathrm{A} \mathrm{BPO}_{4}$ sample was prepared from a equimolar mixture of boric acid and phosphoric acid by the method described elsewhere? ${ }^{9}$. Prior to use, it was calcined at $500^{\circ} \mathrm{C}$ for $2 \mathrm{~h}$ in air.

\section{XPS measurement}

XPS analysis was performed with a Rigaku Denki XPS-7000 spectrometer, using a $\mathrm{MgK} \alpha$ or $\mathrm{AlK} \alpha \mathrm{X}$-ray source operated at $10 \mathrm{kV}$ and $30 \mathrm{~mA}^{1}$. Binding energy values (BE) were corrected by using the value of $285.0 \mathrm{eV}$ for the $\mathrm{C} 1 \mathrm{~s}$ level of the contaminated carbon. The reproducibilities of the $\mathrm{BE}$ values thus obtained were within $\pm 0.2 \mathrm{eV}$.

\section{RESULTS AND DISCUSSION}

$\mathrm{AlPO}_{4}$ $\mathrm{AlPO}_{4}, \mathrm{Al}_{2}\left(\mathrm{SO}_{4}\right)_{3}, \mathrm{Al}_{2} \mathrm{O}_{3}$

Table 1 shows the results of XPS measurements of three solid acids, $\mathrm{AlPO}_{4}, \mathrm{Al}_{2}\left(\mathrm{SO}_{4}\right)_{3}$, and $\mathrm{Al}_{2} \mathrm{O}_{3}$. The $\mathrm{BE}$ of $\mathrm{Al}$ of $\mathrm{AlPO}_{4}$ was nearly equal to that of $\mathrm{Al}_{2}\left(\mathrm{SO}_{4}\right)_{3}$ but was higher than that of $\mathrm{Al}_{2} \mathrm{O}_{3}$. This suggests that the $\mathrm{Al}$ of $\mathrm{AlPO}_{4}$ is more abunding in positive charge than that of $\mathrm{Al}_{2} \mathrm{O}_{3}$. And, the $\mathrm{BE}$ of $\mathrm{O}$ of $\mathrm{AlPO}_{4}$ is approximate to that of $\mathrm{Al}_{2}\left(\mathrm{SO}_{4}\right)_{3}$ but is higher than that of $\mathrm{Al}_{2} \mathrm{O}_{3}$, suggesting that the electron density of $\mathrm{O}$ of $\mathrm{AlPO}_{4}$ is lower than that of $\mathrm{Al}_{2} \mathrm{O}_{3}$. Such $\mathrm{BE}$ data predict that $\mathrm{Al}$ of Al-O-P linkage of $\mathrm{AlPO}_{4}$ will exhibit Lewis acidity by having electron withdrawing power. As the result, the electron density of $\mathrm{O}$ of the Al-O-P linkage will decrease, and the surface basicity of $\mathrm{AlPO}_{4}$ will be weakened by the effect. These predictions agreed with the experimental results (not shown). In addition, the surface acid-base property of $\mathrm{AlPO}_{4}$ is approximate to that of $\mathrm{Al}_{2}\left(\mathrm{SO}_{4}\right)_{3}$, and it differs in the point with its small base amount from $\mathrm{Al}_{2} \mathrm{O}_{3}$. These predictions do not contradict known facts that $\mathrm{Al}_{2} \mathrm{O}_{3}$ has basic sites, but neither $\mathrm{Al}_{2}\left(\mathrm{SO}_{4}\right)_{3}$ or $\mathrm{AlPO}_{4}$ has basic sites.

TABLE 1 The results of XPS measurements of $\mathrm{AlPO}_{4}$, $\mathrm{Al}_{2}\left(\mathrm{SO}_{4}\right)_{3}$, and $\mathrm{Al}_{2} \mathrm{O}_{3}$

\begin{tabular}{lll}
\hline \multirow{2}{*}{ Sample } & \multicolumn{2}{c}{ B.E. / eV } \\
\cline { 2 - 3 } & \multicolumn{1}{c}{$\mathrm{Al} p$} & $\mathrm{O} 1 s$ \\
\hline $\mathrm{AlPO}_{4}$ & $75.4-75.8$ & $532.6-533.1$ \\
$\mathrm{Al}_{2}\left(\mathrm{SO}_{4}\right)_{3}$ & & \\
$300^{\circ} \mathrm{C}$ ( in air) & 75.9 & 532.8 \\
$800^{\circ} \mathrm{C}$ ( in air) & 75.5 & 533.0 \\
$\mathrm{Al}_{2} \mathrm{O}_{3}$ & 74.6 & 531.4 \\
\hline
\end{tabular}


Cristobalite type $\mathrm{AlPO}_{4}$ and amorphous $\mathrm{AlPO}_{4}$

Table 2 shows the results of examining the effects of crystallinity of $\mathrm{AlPO}_{4}$ on the XPS $\mathrm{BE}$ values and surface elemental composition of $\mathrm{Al}, \mathrm{O}$, and $\mathrm{P}$ of $\mathrm{AlPO}_{4}$. The $\mathrm{BE}$ values of the $\mathrm{Al}, \mathrm{O}$, and $\mathrm{P}$ of cristobalite type $\mathrm{AlPO}_{4}$ are not almost different from those of amorphous $\mathrm{AlPO}_{4}$. It is noticed that the composition of $\mathrm{P}$ and $\mathrm{O}$ of amorphous $\mathrm{AlPO}_{4}$ were lower than those of cristobalite type $\mathrm{AlPO}_{4}$ when heated in vacuo at 400,750 , or $1000^{\circ} \mathrm{C}$. This seems to be due to the elimination of $\mathrm{P}$ and $\mathrm{O}$ as a phosphorus oxide from the amorphous $\mathrm{AlPO}_{4}$ because of its thermal instability during high-temperature evacuation processing. Amorphous $\mathrm{AlPO}_{4}$ evacuated at high temperatures is a good catalyst for olefin geometrical isomerisation, while cristobalite type $\mathrm{AlPO}_{4}$ has no activity for the reaction even if it was evacuated at high temperatures. Such a difference could be explained by the easiness of $\mathrm{P}$ and $\mathrm{O}$ (as $\mathrm{P}_{2} \mathrm{O}_{5}$ ) elimination from the amorphous $\mathrm{AlPO}_{4}$.

TABLE 2 The effect of crystallinity of $\mathrm{AlPO}_{4}$ on XPS BE values and surface elemental composition of $\mathrm{AlPO}_{4}$

\begin{tabular}{|c|c|c|c|c|c|c|c|}
\hline \multirow{2}{*}{$\begin{array}{l}\text { Crystallinity } \\
\text { of } \mathrm{AlPO}_{4}\end{array}$} & \multirow{2}{*}{$\begin{array}{l}\text { Evac temp. } \\
\qquad /{ }^{\circ} \mathrm{C}\end{array}$} & \multicolumn{3}{|c|}{ B.E. $/ \mathrm{eV}$} & \multicolumn{3}{|c|}{$\begin{array}{l}\text { Suface elemental } \\
\text { composition }\end{array}$} \\
\hline & & $\mathrm{Al} 2 p$ & $\mathrm{P} 2 p$ & Ols & $\mathrm{Al}$ & $P$ & 0 \\
\hline \multirow{2}{*}{ Cirstobali } & 400 & 75.4 & 134.9 & 7 & 1 & 1.17 & 5.29 \\
\hline & 750 & 75.6 & 135.0 & 532.8 & 1 & 1.18 & 5.30 \\
\hline \multirow{2}{*}{ norphous } & 400 & 75.4 & 134.9 & 532.7 & 1 & 1.10 & 5.08 \\
\hline & 750 & 75.6 & 135.0 & 532.8 & 1 & 1.09 & 5.11 \\
\hline
\end{tabular}

$\mathrm{BPO}_{4}$

As shown in Fig. 1, P2p peak (135.0$135.4 \mathrm{eV}$ ) of the $\mathrm{BPO}_{4}$ sample was located in high energy side than that of $\mathrm{AlPO}_{4}(134.9$ eV). $\mathrm{XRD}$ analysis indicates that $\mathrm{BPO}_{4}$ sample is mainly composed of crystalline $\mathrm{BPO}_{4}$. There is, however, no literature data of $\mathrm{BE}$ of the $\mathrm{P} 2 p$ peak of $\mathrm{BPO}_{4}$. If the $\mathrm{BPO}_{4}$ sample is isomorphic with $\mathrm{AlPO}_{4}$, if it consists only of pure crystalline $\mathrm{BPO}_{4}$, and if the electronegativity of $B$ is higher than $\mathrm{Al}$, it can be understood that $\mathrm{P} 2 p$ peak (135.0-135.4 eV) of the $\mathrm{BPO}_{4}$ sample is located in higher energy side than $\mathrm{AlPO}_{4}$ $\mathrm{P} 2 p$ peak $(134.9 \mathrm{eV})$. But it is difficult to

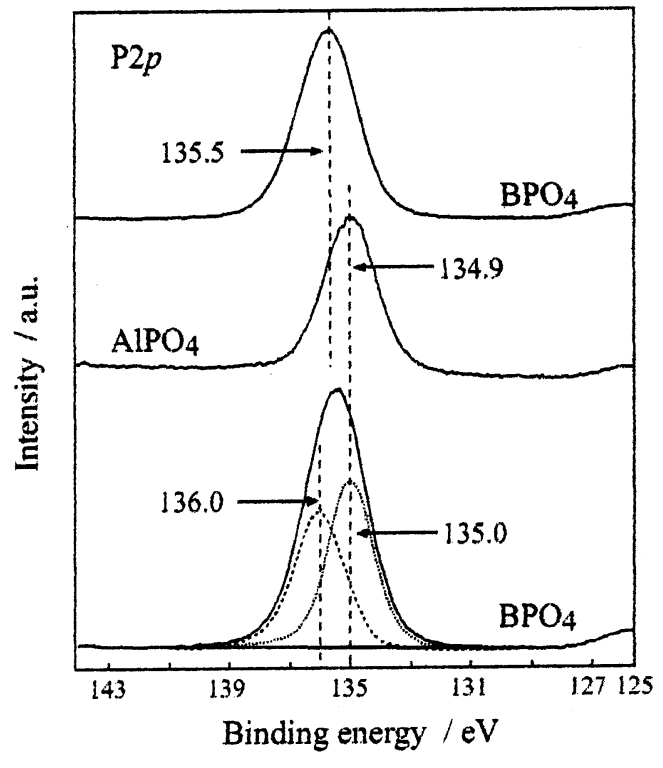

FIGURE 1 XPS P2 $p$ spectra of $\mathrm{BPO}_{4}$ and $\mathrm{AlPO}_{4}$. 
consider that the electronegativity of $\mathrm{B}$ is higher than that of $\mathrm{Al}$, because $\mathrm{B}$ is a metalloid. Therefore, the fact that $\mathrm{P} 2 p$ peak $(135.0-135.4 \mathrm{eV})$ of the $\mathrm{BPO}_{4}$ sample is located in higher energy side than $\mathrm{P} 2 p$ peak $(134.9 \mathrm{eV})$ of $\mathrm{AlPO}_{4}$ suggests that some materials except for crystalline $\mathrm{BPO}_{4}$ exist on the surface of the $\mathrm{BPO}_{4}$ sample. Therefore, the deconvolution of $\mathrm{BPO}_{4} \mathrm{P} 2 p$ peak was carried out by assuming that it agrees with $\mathrm{AlPO}_{4} \mathrm{P} 2 p$ peak (Fig. 1). As the result, the other peak appeared in the higher energy side than that of $\mathrm{BPO}_{4} \mathrm{P} 2 p$ peak. This new peak $(\mathrm{BE}=$ $136.0 \mathrm{eV}$ ) seems to be assigned to a phosphorus compound like $\mathrm{P}_{2} \mathrm{O}_{5}$ judging from the literature ${ }^{10}$.

As seen in Fig. 2, O1s peak (BE $=533.0-$ $533.3 \mathrm{eV}$ ) of the $\mathrm{BPO}_{4}$ sample was located to the higher energy side than $\mathrm{AlPO}_{4} \mathrm{Ols}$ peak $(\mathrm{BE}=532.7-533.1 \mathrm{eV})$. The result of the deconvolution of $\mathrm{BPO}_{4} \mathrm{O} 1 \mathrm{~s}$ peak by assuming that it agrees with $\mathrm{AlPO}_{4} \mathrm{O} 1 s$ peak suggested that there is the other peak in the higher energy side than that of $\mathrm{BPO}_{4} \mathrm{O} / s$ peak (Fig. 2). It agreed with that of $\mathrm{H}_{3} \mathrm{BO}_{3}$ or $\mathrm{B}_{2} \mathrm{O}_{3} \mathrm{O} 1 s$ peak. This fact indicates the existence of $\mathrm{H}_{3} \mathrm{BO}_{3}$ or $\mathrm{B}_{2} \mathrm{O}_{3}$ on the surface.

In the XPS wide scan spectrum of $\mathrm{BPO}_{4}$ (Fig. 3), there were three peaks, O1s peak, $\mathrm{P} 2 p$ peak, and the third peak in which B1s peak overlapped with $\mathrm{P} 2 s$ peak. Previously, we supposed that the peak having lower binding energy of the two peaks obtained by carrying out the decomvolution of the $\mathrm{B} 1 s$ peak would be due to $\mathrm{B}$ of $\mathrm{BPO}_{4}$ without examining the $\mathrm{BPO}_{4}$ XPS wide scan spectrum ${ }^{1}$. As mentioned above, however, it has been proved that $\mathrm{B} 1 s$ peak overlapped with $\mathrm{P} 2 s$ peak. Therefore it is necessary to discuss the assignment of the peak in the

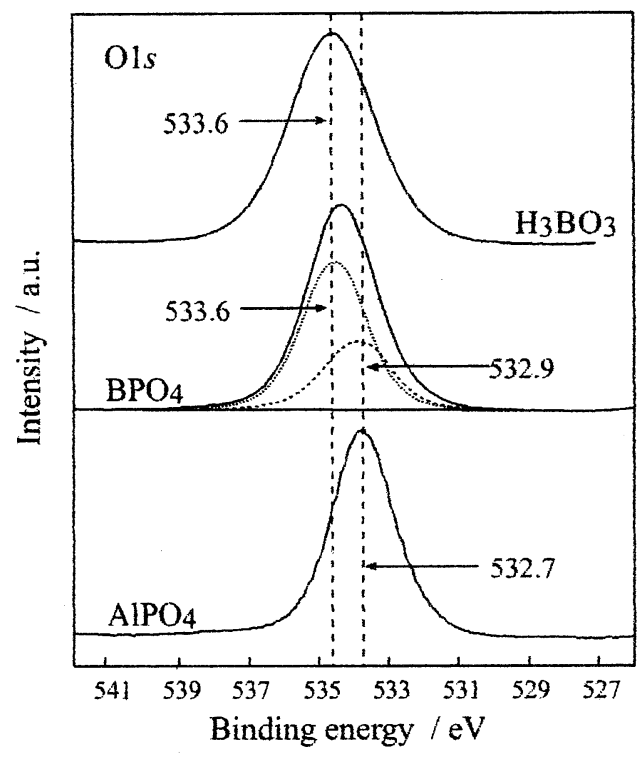

FIGURE 2 XPS Ol s spectra of $\mathrm{H}_{3} \mathrm{BO}_{3}$, $\mathrm{BPO}_{4}$, and $\mathrm{AlPO}_{4}$.

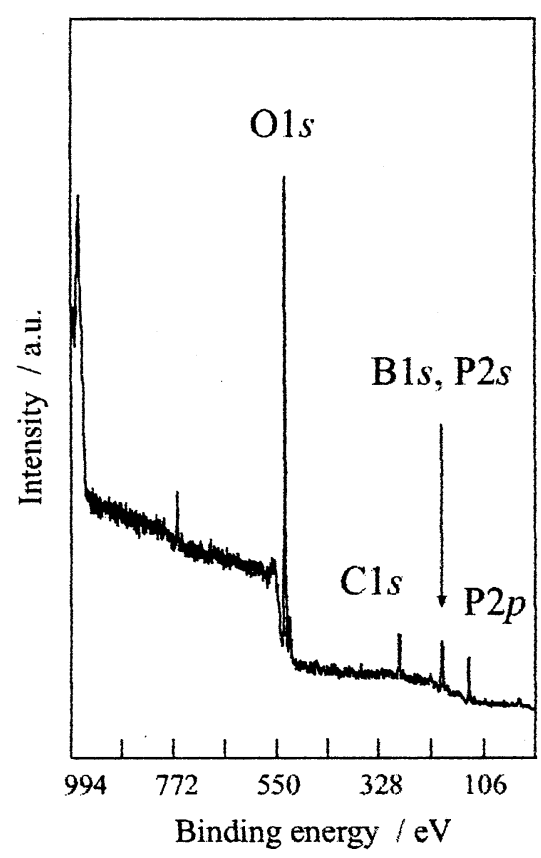

FIGURE 3 XPS wide scan spectrum of $\mathrm{BPO}_{4}$. 
lower energy side in detail. It was anticipated that the $\mathrm{Bl}$ s peak of $\mathrm{BPO}_{4}$ would be located in higher energy side than the $\mathrm{B} 1 s$ peak of $\mathrm{H}_{3} \mathrm{BO}_{3}$ or $\mathrm{B}_{2} \mathrm{O}_{3}$, because the binding energy of $\mathrm{Al}$ of $\mathrm{AlPO}_{4}$ was higher than that of $\mathrm{Al}_{2} \mathrm{O}_{3}$. But the peak was not found in the vicinity (Fig. 4). This fact indicates that $\mathrm{BPO}_{4} \mathrm{~B} 1 s$ peak agrees with $\mathrm{B} 1 s$ peak of $\mathrm{H}_{3} \mathrm{BO}_{3}$ or $\mathrm{B}_{2} \mathrm{O}_{3}$. Then, by assuming that $\mathrm{B} 1 \mathrm{~s}$ peak of $\mathrm{BPO}_{4}$ agrees with that of $\mathrm{H}_{3} \mathrm{BO}_{3}$ or $\mathrm{B}_{2} \mathrm{O}_{3}$, the deconvolution of $\mathrm{BPO}_{4} \mathrm{~B} 1 s$ peak was carried out. As the result, the other peak appeared in the low energy side and it agreed with $\mathrm{AlPO}_{4} \mathrm{P} 2 s$ peak (Fig. 5). Therefore it was attributed to $\mathrm{BPO}_{4} \mathrm{P} 2 s$ peak. Reversely, when the existence of $\mathrm{AlPO}_{4} \mathrm{P} 2 s$ peak (or $\mathrm{BPO}_{4} \mathrm{P} 2 s$ ) is assumed, the peak which agreed with $\mathrm{B} 1 s$ peak (or $\mathrm{BPO} 4 \mathrm{~B} 1 s$ ) of $\mathrm{H}_{3} \mathrm{BO}_{3}$ or $\mathrm{B}_{2} \mathrm{O}_{3}$ appears in the higher energy side as the result of carrying out the deconvolution of $\mathrm{BPO}_{4} \mathrm{~B} 1 s$ peak. This means that $\mathrm{BPO}_{4} \mathrm{~B} 1 s$ peak agrees with $\mathrm{B} 1$ s peak of $\mathrm{H}_{3} \mathrm{BO}_{3}$ or $\mathrm{B}_{2} \mathrm{O}_{3}$.

The above results indicate that the peak in lower energy side of the $\mathrm{B} 1 s$ peak (2 peaks) of the $\mathrm{BPO}_{4}$ sample can is be attributable to $\mathrm{B} 1 s$ peak but to $\mathrm{P} 2 s$ peak of $\mathrm{BPO}_{4}$ and that the phosphorus compound like $\mathrm{P}_{2} \mathrm{O}_{5}$ and unreacted $\mathrm{H}_{3} \mathrm{BO}_{3}$ or its condensation compound exist on $\mathrm{BPO}_{4}$ surface.

\section{CONCLUSION}

1) The surface acid-base property of $\mathrm{AlPO}_{4}$ is approximate to that of $\mathrm{Al}_{2}\left(\mathrm{SO}_{4}\right)_{3}$, and it is different in the point with smaller base amount from that of $\mathrm{Al}_{2} \mathrm{O}_{3}$.

2) When amorphous $\mathrm{AlPO}_{4}$ is heat-treated in vacuo, the phosphorus and oxygen of its

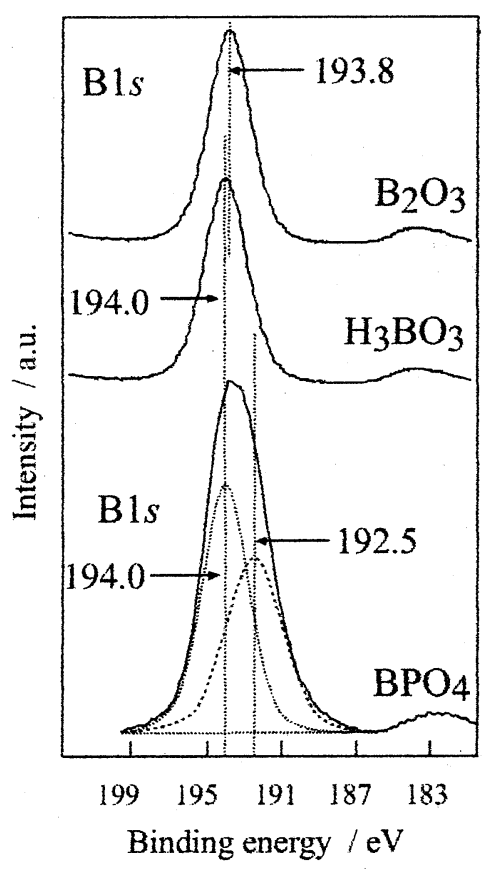

FIGURE 4 XPS B $1 s$ spectra of $\mathrm{B}_{2} \mathrm{O}_{3}$, $\mathrm{H}_{3} \mathrm{BO}_{3}$, and $\mathrm{BPO}_{4}$.

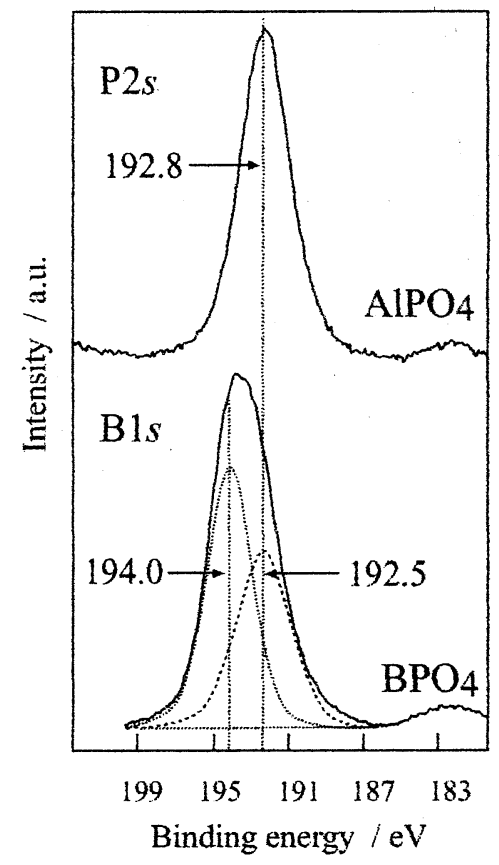

FIGURE 5 XPS. P2 $s$ spectra of $\mathrm{AlPO}_{4}$ and $\mathrm{B} 1 s$ spectra of $\mathrm{BPO}_{4}$. 
surface desorbs.

3) Unreacted $\mathrm{H}_{3} \mathrm{BO}_{3}$ or its condensation compound and phosphorus compound like $\mathrm{P}_{2} \mathrm{O}_{5}$ exist on $\mathrm{BPO}_{4}$ surface.

\section{REFERENCES}

1. N. Okazaki, M. Takahashi, H. Murai, and A. Tada, Phosphor. Res. Bull., 9, 63-68 (1999).

2. H. Itoh, A. Tada, and K. Tanabe, Chem. Lett., 1567-1568 (1981); H. Itoh, A. Tada, and H. Hattori, J. Catal., 76, 235-237 (1982); A. Tada, Materials Chem. Phys., 17,145-159 (1987); H. Itoh, N. Okazaki, Y. Imizu, and A. Tada, Phosphor. Res. Bull, 4, 19-24 (1994); A. Tada, H. Itoh, N. Okazaki, K. Yamada, and Y. Imizu, Phosphor. Res. Bull., 4, 25-28 (1994).

3. A. Tada, T. Yoshino, and H. Itoh, Chem. Lett., 419 (1987); A. Tada, N. Takahashi, N. Okazaki, and Y. Imizu, Phosphor. Res. Bull., 1, 273-278 (1991).

4. Y. Imizu, S. Aoyama, H. Itoh, and A. Tada, Chem. Lett., 1455-1456 (1981); A. Tada. H. Suzuka and Y. Imizu, Chem. Lett., 423-424 (1987); N. Okazaki, Y. Shiina, Y. Yamamoto, and A. Tada, Phosphor. Res. Bull., 8, 131-136 (1998).

5. S. Gao and J. B. Moffat, J. Catal., 180, 142-148(1998).

6. F. Carvani, T. Monti, and D. Paoli, Studies in Surface and Catalysis, 130, 2633-2638 (2000); C. Dume and W. F. Holderich, Appl. Catal. A, 183, 167-176(1999); Graham J. Hutchings, et al., J. Catal., 188, 291-299(1999).

7. A. Tada, N. Okazaki, Y. Murakami, K. Sakamoto, and M. Tsuhako, Phosphor. Res. Bull., 6 , 197-200 (1996).

8. H. Itoh, A. Tada, and K. Tanabe, Chem. Lett., 1567 (1981).

9. A. Tada, N. Murakami, N. Okazaki, and H. Itoh, Phosphor. Res. Bull, 5, 115-120 (1995).

10. John F. Moulder, et al., Handbook of X-ray photoelectron spectroscopy, Edited by Jill Chastain (Perkin-Elmer corporation, 1992), p. 59. 